\title{
Da miséria absoluta para a miséria relativizada
}

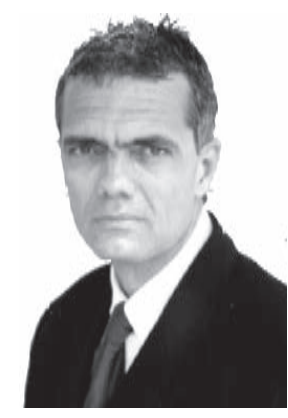

Marco Antonio Guimarães da Silva,Med.Dr.Sci.

marco@atlanticaedu.com.br

A recente declaração do Sr. Lula da Silva, envolvendo a elite, a bolsa família e a bolsa acadêmica, me fez refletir sobre o tema.

As bolsas acadêmicas oferecidas pelos órgãos fomentadores de investigação científica (CAPES, CNPq, Fundaçóes Estaduais de Amparo à Pesquisa, etc.) destinam-se à formação de massa crítica.

Ainda com uma colocação abaixo dos países emergentes, o investimento que se tem feito nessa área, no país, tem demonstrado que o caminho parece ser esse. Mesmo perdendo para Índia, China, Rússia e Coréia do Sul o Brasil ocupa o 15 lugar no ranking mundial, no quesito artigos publicados em revistas, com crescimento de $33 \%$ nos dois últimos anos. Já formamos doutores em ritmo semelhante ao de paises ricos, ocupando o $12^{\circ}$ lugar no ranking mundial, ainda abaixo da Argentina e Chile, quando se leva em conta a proporção populacional. De qualquer forma, apesar de algumas distorções, parece que o investimento que se tem feito na área começa a dar resultados, que serão otimizados com a experiência que o tempo se encarregará de oferecer a grande quantidade dos recém-doutores.

A pouca intimidade que tenho com relação ao tema da bolsa família me faz buscar algumas informaçóes na mídia escrita e fico a par de que esse programa já beneficia 46 milhóes de brasileiros, aproximadamente um quarto de toda a nossa população. $\mathrm{Na}$ tentativa de maiores esclarecimentos, recorro também à página eletrônica que o Ministério da Saúde mantém no ar e encontro ali a seguinte informação: "O BOLSA FAMÍLIA é um programa de transferência de renda destinado às famílias em situação de pobreza, com renda per capita de até R\$ 120 mensais, que associa à transferência do benefício financeiro o acesso aos direitos sociais básicos - saúde, alimentaçâo, educação e assistência social."

Chama minha atenção a parte da informação que grifei e me vem à cabeça a seguinte pergunta: onde diabos estão a saúde, a educação e assistência social prometidos pela informação colhida no site?

Os profissionais da área de saúde conhecem muito bem o sofrimento que os menos privilegiados financeiramente tem para obter uma vaga ou atendimento para si em um hospital. Esclareça-se, embora náo seja o momento para tal, que mesmo os que podem e pagam planos de saúde têm muitas dificuldades para obter atendimento ambulatorial à altura das elevadas quantias que mensalmente desembolsam. Obter uma vaga em CTI, ainda que com exorbitante pagamento, igualmente não é a tarefa fácil. Os pais, por sua vez, também sabem da dificuldade de obtenção de uma vaga para os seus filhos em escolas publicas. Obter a tal vaga em escola pública é tarefa hercúlea que inclui noite insone em longas filas. E finalmente, quando se consegue a vaga, não há a garantia de que o aluno conseguirá aprender alguma coisa.

Não poderia, por falta de conhecimento, criticar a bolsa família. O benefício pode estar carregado de boas intençôes, conseguindo, realmente, levar para a população alvo o alimento imprescindível. Mas será que o caminho é esse, ou só esse? Não estaríamos criando um mecanismo puramente assistencialista que traria como conseqüência uma inevitável acomodação? Teriam os beneficiários dessa bolsa alguma perspectiva ou esperança de trabalho digno e educação para os seus filhos?

$\mathrm{O}$ assistido durante anos, ou talvez durante toda sua existência, fora acostumado com alimentaçáo escassa que mal permitira a garantia da sua própria existência. Aparece então a bolsa família e agora ele sai da miséria absoluta para uma miséria relativizada, brindando com louvores o pai governo que veio para salvar-lhe.

Tento inutilmente resistir à tentação de buscar na filosofia alguma explicação para o fato, mas náo posso deixar de fazer uma incursão nessa área. Audaciosamente, proponho, então, uma leitura para a situação.

"Pão e água proporcionam o maior dos prazeres quando são levados à boca dos que tem necessidade" (Carta a Meneceo - Epicuro, 341-270 AC). Para Epicuro o limite do prazer se encontra na completa ausência de dor e surge tanto da satisfação do desejo como no posterior equilíbrio alcançado. $\mathrm{O}$ raciocínio epicurista, amparado no empirismo, associa a origem do conhecimento à experiência sensível. A moral epicurista também não é do tipo que possa ter efeitos sociais de longo alcance. É uma concepção que tende a brindar um indivíduo ou grupo de indivíduos ligados por laços de amizade. Essa idéia talvez explique porque saciar a fome de alguém pode trazer tantos louvores para o "benfeitor". Os repetidos cheques doados mensalmente antecipam a presença real e efetiva desse benfeitor. A benfeitoria estabelece laços quase que pessoais com o beneficiado e cria uma rede de intimidade ampliada mais ainda com a imagem de expobre, coitado, que o benfeitor insiste em manter. Seria esse o motivo da conquista de tanta aprovação e admiração?

Em carta a Meneceo, Epicuro oferece estratégias muito eficientes para superar as tensóes, os medos e as limitaçóes, enfim, a ultrapassagem do sofrimento humano. A linha de argumentos utilizada no livro poderia ser comparada às modernas estratégias da reestruturação cognitiva, cuja máxima reside em arranjar a "cabeça” para chegar à felicidade. Parece que no caso assistencialista que aqui discutimos esse arranjo se inicia e termina no trato digestivo. 